\begin{tabular}{r|c} 
Dossier & LIQUDD TOURNATISM: \\
& trends in amplification of the field \\
$\begin{array}{r}\text { Copyright } \odot 2012 \\
\text { SBPjor / Associação } \\
\text { Brasileira de } \\
\text { Pesquisadores em } \\
\text { Jornalismo }\end{array}$ & $\begin{array}{l}\text { ANELISE RUBLESCKI } \\
\text { Universidade Federal de Santa Maria, Brazil } \\
\text { Aniversidade Federal do Rio Grande do Sul, Brazil } \\
\text { Unive ROCHA DA SILVA }\end{array}$
\end{tabular}

\begin{abstract}
This article derives from a broader investigation which discusses the metamorphoses that are established for the mediation and the capability for processing of the news in the culture of the convergence and digitalization. As a direct result of the investigation seven trends to enlarge the boundaries of the field are highlighted: 1) diffuse journalism, 2) residual recovery journalism, 3) deepening of journalism in collaboration, 4) predominance of news centered on the reader, 5) more value given to local content, 6) personalization of the fruition of the news, and 7) plurality of voices and framings with regard to the same fact. Methodologically, it is a theoretical and critical article, developed from review of the literature and empirical observation.
\end{abstract}

Keywords: Journalism. Liquid Journalism. Journalistic field.

\title{
JORNALISMO LÍQUIDO tendências de ampliação do campo
}

RESUMO - O artigo deriva de uma investigação mais abrangente que discute as metamorfoses que se instauram para a mediação e para a processualidade da notícia na cultura da convergência e da digitalização. Como resultado direto da investigação sinalizam-se sete tendências de alargamento das fronteiras do campo: 1) jornalismo difuso, 2) jornalismo de recuperação residual e 3) jornalismo de aprofundamento em colaboração, 4) predominância de notícias centradas no leitor, 5) valorização do conteúdo local, 6) personalização da fruição das notícias e 7) pluralidade de vozes e enquadramentos sobre um mesmo fato. Metodologicamente, é um artigo de cunho teórico-crítico, desenvolvido a partir de revisão bibliográfica e observação empírica.

Palavras-chave: Jornalismo. Jornalismo líquido. Campo jornalístico. 


\section{INTRODUCTION}

The Polish sociologist Zygmunt Bauman uses the metaphor of the liquid to describe the present time, characterized by the impossibility to maintain stable forms commonly recognized as characteristic of modernity in its broadest sense and, for the purposes of this article ${ }^{1}$, also of journalism. The author, referring to the present moment as "liquid modernity" or "liquid-modern society", points out:

Liquid-modern is a society in which the conditions under which its members act change in a shorter time than that required for consolidation, in habits and routines, of the forms of action (BAUMAN, 2007, p.7).

In this sense, liquid journalism is an expression that can be understood on two levels. On the first, of a conceptual nature, journalism is shown as a mediating institution, like many other institutions such as state, church, school or even family. With this approach, the term liquid journalism was used by Mark Deuze (2006) in an article to question the legitimacy and credibility still desired by the journalistic field. On the second level, related to journalism as a social practice, the term refers to the news flows that emerge between various websites, many of which go beyond the institutional newsrooms, but that really fit into the news circuit.

One observes that the problematic of liquid journalism is inserted into a new media ecology in which the configuration of a communicational system is integrated by connections that provides us with a steady stream of news and interactions among users from various subsystems ${ }^{2}$, being particularly marked by the disruption of spatial and temporal boundaries that characterized journalistic practices in modernity.

It is understood, however, that liquid journalism does not mean the end of journalism, but it may signal the agony of a given model of informative journalism. Liquid journalism is, first of all, an unstable scenario, open, permeated by a continuum of changes that apparently trigger a process of enlargement of the boundaries of the field, whose balance point still remains an open question.

\section{Journalism as a social field}

A social field is a socially structured space. For Pierre Bourdieu (2010), it is a space that is organized and provokes contention, with rules, hierarchical structures, functions and positions. Rodrigues (1990, p. 152) points out that a field must be understood as a social institution, a sphere of legitimacy. In this sense, the field of media is one "whose expressive and pragmatic legitimacy is by nature a legitimacy delegated 
by the other social fields".

One observes that the legitimacy of journalism is at the same time delegated by the other fields and constituted by the journalistic field to the exact extent that it can be referentially faithful in its representation of the world to situations of truth typical of the other fields. The symbolic efficacy of journalistic discourse, therefore, necessarily aggregates the properties of the discourse produced by the field of media to the properties of the one who pronounces it and, finally, to the properties of the institution that authorizes its pronunciation. In the case of journalism, the social practice is "authorized" by both sources (other fields, who delegate their social public representation to the press) and the reader, who delegates the power to deliver a version of the more relevant aspects of what occurred in a given circumstance. It is in this balance between the fields that the legitimacy of the press and journalists lies.

In liquid journalism, the instability more sensitive to the constitutive precepts of the field and of major consequences for the mediating role of Journalism is the rupture of the emission pole, until then made predominantly vertical based on the professional newsrooms.

Readers start to have direct access to primary sources (personalities, institutional and business websites, for example) with wide and easy access to the information, as well as technical resources for news publishing in a way detached from the mediation of the major press media. Thus the reader becomes a content producer that potentially assumes shifting identities during the process of building online news. If the interagent subject at a given moment is the reader and at another, is the content producer, the situation becomes more complex and what was solid becomes liquid.

The primary sources of information, which basically depend on the media in order to obtain wide public visibility, open their own service and communication portals, building spaces of visibility and direct interaction with the reader and, in some cases, even for interpellation of the established press itself.

They are institutions that until recently competed for space in the news media and now - simultaneously with the search for insertion in the traditional media, which continues - by-pass the old paradigm of centralized and vertical news production. They are social actors (individuals or companies) that invest in their own spaces of visibility by the public, benefiting from the network configuration and contributing to the flow of information that characterizes liquid journalism.

Government agencies such as the Presidency of the Republic, 
the Federal Supreme Court, the Chamber of Deputies, social movements such as the Landless Peasants Movement (MST), churches such as the Catholic Church or the Assembly of God, all have websites, with different products and services that enable access to information and ensure interaction with their press advisers. Sometimes issuers, sometimes sources, the boundaries of the role of each institution in the journalistic scenario become diffuse.

Nevertheless, a social field is conceptually a structured space of positions, hierarchical structures and functions. That is why a social field is also an area of contention between social actors working in it for the control of the capital that forms it.

Bourdieu (2010), in the analysis of the various capitals that form the social fields, supports the existence of the symbolic power, superior to all other powers, because it gives meaning to the world and moves through all the fields. For the author, the symbolic power is then, "this invisible power that can be exercised only with the complicity of those who do not want to know that they are subject to it or even that they exercise it" (BOURDIEU, 2010, p. 11-12). The need can be seen again here for tacit legitimization of the power by the other so that its exercising is effective, since as stated earlier, legitimacy is delegated. In this sense, one observes that:

On taking control of the narratives in discourses, citizen-reporters invest themselves with the symbolic power, .previously hegemonic of the traditional mass media. [...] Another disruption occurs regarding the interactions between public and media. If before the social relations that were mediated by means of mass dissemination of information took place in a one-way flow of communication, currently this interaction also occurs in a plural and interdependent way, in which users transcend the monological verticality and structure of the oligopolies of information (ALMEIDA, 2009, p.37).

This decentralized mediation of liquid journalism invigorates the questioning regarding who is legitimate for publishing, a central pillar of the journalistic field until recently, since it involves the journalistic habitus $^{3}$ itself. It is in this sense that one can consider that in liquid journalism - from the moment that social media start to have the visibility and also include information of journalistic relevance, affecting and being affected by corporative journalism - there is what Palacios (2006) calls "enlargement" of the journalistic field.

\section{Guidelines for the enlargement of the journalistic field}

From a study based solely on blogs (only one of the digital media whose set forms the blogosphere), Palacios (2006) demonstrates 
that these blogs are gaining an increasingly larger space in the media, and are also competing for the audience with traditional journalistic companies. It is a movement of expansion of the field of journalism, with the tensions, continuities, potentialities and discontinuities that characterize this type of process.

What is observed is that at the time in which different communicational-journalistic subsystems - until then nonexistent in journalism - start to dialog more and more among themselves and with the traditional media, and these latter among themselves and in a coreferential way, an unstable, liquid scenario takes shape, requiring other looks for its apprehension and comprehension.

In liquid journalism the analytical emphasis seems to lie more on the processing than in what occurs both in the journalistic field and in every blog or website. The generation of journalistic meanings moves away from the perspective of the field normatized exclusively based on professional journalism and turns to the relationships established between the different subsystems, causing the enlargement of the field.

Palacios (2006) and Foletto $(2007,2009)$ refer to three guidelines for enlargement of the field based on the context of journalism on the web: 1) diffuse journalism, 2) residual recovery journalism and 3) deepening of journalism in collaboration. In this article the three inferences of the authors are maintained, but there are indications that the journalism field has been also expanding in four other directions: a) predominance of news centered on the reader, b) more value given to local content, c) personalization of the fruition of the news and d) plurality of voices and framings with regard to the same fact. Following this, we analyze how each trend fits in and shapes liquid journalism.

\section{Diffuse journalism}

Diffuse journalism is the nomenclature proposed by Palacios for the use of blogs as tools for reporting or as a witness from the place where the facts that have journalistic relevance are happening.

\footnotetext{
Voice is given to those who are at the "scene of the crime", seeing with their own eyes the reality which is offered them to see. Bloggers use their privileged position in a certain place to report what they see in a more direct, personal way, which results in not respecting all the rules of the journalistic field. The verification, which ends up being of lower quality, is compensated by the increased use of the opinion of the blogger [...] (FOLETO, 2007, p. 5-6).
}

The warblogs, blogs maintained by ordinary people from areas where armed conflicts occur, are examples of diffuse journalism, like 
Twitter has proven to be tool specially used for timely interventions in catastrophes or emergencies.

Palacios (2006) and Foleto (2007) indicate as the main forces of this kind of journalism the multi-voicing and the direct testimony of the authors from the place of the happening. With frankness, they point to the "inability to provide an interpretative context so that the shower of information can acquire meaning and become knowledge" (FOLETO, 2007).

This is so because the potentiality that diffuse journalism shows is punctual. From the moment in which the continuation of the coverage requires aggregating data analysis, contextualizations, correlations, i.e., the deepening of the information available, other guidelines are formed to expand the field of journalism. One of them is the deepening of collaboration.

\section{Deepening of journalism in collaboration}

There is clearly a trend towards the growth of journalism in collaboration as a natural consequence of the expansion of the web. The relational characteristic of blogs and digital media enhances the production of journalistically relevant information from multiple actors/ interagents. Journalism in collaboration is also characterized by the comments and especially the links, which enable an interconnection between fragments of complementation that together, contribute a larger informative load to the original posting.

Some of the most respected publications in the worldwide press have already been wagering on the higher value given by the readers through collaborative journalism.

\footnotetext{
While most newspapers face the question of the readers' comments as a permanent headache, the Post [The Washigton Post $]^{4}$ decided to transform public participation into its strategic goal in the war for audience in the extremely competitive market for the providing of information on the Internet. The new model for publication of readers' comments on the webpage of the newspaper is unprecedented in the Internet, cost several million dollars and creates a new standard regarding the relationship between journalists and public (CASTILHO, 2009, online).
}

One observes that the participation encouraged by the newspaper differs from what is still practiced in Brazil by the consolidated media, where the tonic of participation revolves around the transmission of material, especially videos or photos of situations witnessed by the interagent. What The Washigton Post seeks, and that tends to enlarge the boundaries of journalism through collaborations, is the deepening of 
the content and the narrowing of relationships, not just of the newsroom with the readers, but also of the discussions among the interagents.

\title{
Residual information recovery journalism
}

Residual information recovery journalism is considered by Palacios (2006) to be a journalism that expands the boundaries of the field because it expands the topics under discussion in the social fabric.

This is a trend to enlargement of the field that results from websites that seek to give visibility to new themes or points of view and from the very freedom that each interagent on the web has to provide visibility for news, events and facts that have not gained the relevance that these actors consider necessary in the traditional media. What is observed is that these new centers of emission of journalistic information within the field allow a greater diversity of events that can be classified as news.

\section{News centered on the reader}

A guideline for enlargement of the journalistic field takes shape here that signals a shift in values that were characteristic of informative journalism. What is inferred is that the competition for attention, time and preference of the reader makes the news to no longer be centered on the newsroom criteria and start to be more and more centered on the preferences of the reader. For Castilho (2011, online):

\begin{abstract}
Until now journalists and newspapers relied on the idea that they knew what was good for the reader. The new ideas totally inverted this process, because it is the public who will say what it wants to be investigated and reported. It is not a simple change, because it affects a set of values and routines associated with the informative activity.
\end{abstract}

This means that in liquid journalism, the reinvention of the journalistic companies as a channel of communication is being done through a significant change in values. These values were critically evaluated by Roland Barthes when, in Mythologies (2001), he identified as one of the rhetorical figures of the myth the quantifying of quality. For the French semantics expert, contemporary capitalism is expressed aesthetically by the pure quantification of effects, i.e., a work is judged more by the effects it produces and the expectations of its readers than by its structural constitution. In this perspective, liquid journalism would be one of the most effective expressions of latter-day capitalism precisely because it reconfigures the modes of production based on the apparently autonomous desires of readers. 


\section{More value given to local content}

Over the last few decades, the journalism of the conglomerates reduced the space devoted to local news in newspapers, radio and TV stations as a direct consequence of the retrenchment in the newsrooms (CASTILHO, 201 1a). The situation seems to lead journalism to a crossroads, because a survey released in March 2011 by the Monitor and Pew Internet institutes, both based in the United States, showed that interest in community issues is today two times greater than five years ago.

Research has shown that social networks like Facebook and Orkut are now responsible for $32 \%$ of local information consumed by Americans. In second place came the blogs with 19\%, messages via mobile phone with $12 \%$, and micromessages of Twitter with $7 \%$. The remaining $30 \%$ are distributed among the media of the conventional press (CASTILHO, $2011 \mathrm{a}$ ), especially through the aggregating websites.

The increased value given to local content is not just an American phenomenon:

In the Netherlands, Germany and Sweden, researches made by advertising and marketing companies also detected the same migration to the Internet of those interested in local affairs. It is a phenomenon that alters radically the informative ecology in the urban areas because it takes away from the newspapers a loyal public, especially the subscribers, at the same time in which it enlarges the users ' interest in local affairs, thanks to the greater thematic diversification (CASTILHO, $2011 \mathrm{la}$, online).

In Brazil, no updated research on the phenomenon was located, but the reduction of space devoted to community issues is visible, except in cases of major natural tragedies, crimes and accidents.

In reality, the growing demand for local news is not surprising. In 2003, Fernandes, based on a bibliographic research of the works of ten Brazilian, European and American authors ${ }^{5}$ covering the period 19622001 , concludes that the news-value "proximity" is the most relevant for the readers, surpassing even "currency", the second most mentioned criterion. The trend to enlargement of the field here is operational and can lead to a significant metamorphosis for journalism as a mediating space.

\footnotetext{
At the same time in which the demand grows, newspapers are powerless to provide community coverage, because this implies tripling and even quadrupling their reporting teams devoted to local themes, which is impractical in the current cash flow situations of most newspapers and radio or TV stations (CASTILHO, 2011 , online).
}

Journalism must choose between investing in what the public is interested in reading, taking on the expenses that result from a local coverage that attracted readers, or review their role as mediators in the 
fastest growing segment in liquid journalism.

\section{Personalization of information}

In 2005, during the annual meeting of the International Consortium of Investigative Journalists, an American entity that congregates 94 investigative reporters from 48 countries, the journalist and professor Rosental Calmon Alves ${ }^{6}$ summed up what in this article infers regarding liquid journalism: we are entering an era of "I-centric" media: what matters is that they bring the content I want when I want, in the format I want, but only when I want.

In part, the statement refers to the tendency toward enlargement of the field of journalism by news centered on the interest of the readers, and no longer, necessarily, on the importance of the events from the perspective of the newsrooms, as discussed earlier. It is also a characteristic of online journalism itself, as pointed out by Bardoel and Deuze (1999), although, at that time, in a narrower sense, referring to the forwarding of newsletters by e-mail or to the viewing of the first page of the website by the previous options of the reader ${ }^{7}$.

But the trend of enlargement of the field from this perspective - with all the consequent implications for journalism as a disciplinary space - is another exteriority of liquid journalism: the personalization of the informative fruition based on criteria of the reader himself.

This personalization of the fruition of the news can be considered from two aspects: the origin and the thematic focus. The personalization by areas or themes of interest is articulated with the principle of the Long Tail (ANDERSON, 2006), in which there is a growing tendency to seek and/or aggregate content from websites specialized in this or that subject.

On one hand, it is a trend that draws close to the abovementioned search for local news, because, although there the criterion is geographical, it remains a centralization of news according to interests of a community, even though limited spatially. But, on the other hand, it moves away from it since even though personalization also revolves around areas of interest, it is a personalization that benefits from the network society and the globalization of flow of information, where, hypothetically, all information would be equally available. It is a tendency toward aggregation and personalization of content along the lines of the "global village" (MCLUHAN, 2005).

In this sense, the expansion of the journalistic field is not larger (for the time being) only because most news circulating online still 
comes from the traditional journalism companies. It is a trend toward enlargement of the field that is closely related to "journalism centered on the interests of the reader" in which it does not suffice to give the news: it needs to circulate and be recommended.

Like any scenario in delimitations, only the continuance of the process will bring any new possible certainties, even temporarily. However, the fact is that liquid journalism is a practice of personalization, both of fruition in general and of thematic clippings made by the reader.

\section{Plurality of voices and framings with regard to the same fact}

The seventh trend of enlargement of the journalistic field results from the essence of liquid journalism: the porosity between the situations of the reader, journalists and sources. It is related directly to the emergence of new practices and social spaces and also includes diffuse and collaborative journalism, which also tend to keep expanding, but goes beyond the more authorial characteristics that are relevant to it. It is a trend of enlargement of the field which is articulated directly with the increased circulation of news in the social fabric and with multilevel mediation, characteristic of liquid journalism.

There are many diverse phenomenal manifestations that are gradually shaping this trend toward expansion of the field. It is a trend that is evident in journalism, for example, when one observes the consolidation of the press observatories and other formalized spaces for monitoring the media (which have always existed in restricted spaces) based on the technical conditions of visibility and circulation of criticism of products and processes of the media. This enlargement also occurs with the discussions introduced by the reader in the media space, in which each news item is driven by and receives direct feedback from the expanded visibility. During the filtering, critical republications, expansion, or recommended reading add to a plurality of voices and framingss.

It is also here that the "source media" (SANT'ANNA, 2009) will cause the enlargement of the boundaries of journalism, as more institutional sources find their respective spaces in order to aggregate their voice directly into the media agenda, although, as far as this article allows one to foresee, they continue fighting for space in the consolidated media. The enlargement tends to occur by juxtaposition and not by substitution, and includes, among others, alternative journalism websites, to the extent that the latter also seek space to bring themes little or inadequately covered by the media. 


\section{Final comments}

Changes are part of the history of Journalism, since it is a socio-communicative practice. The same applies to the news, seen as the narrative of social events. Changeable as Journalism itself, the news has adapted to the supports and has made from them different means of expression. It changed along with the modes of production, with the professional culture and with the journalistic organizations. In the process, it passed through different stages, it changed its shape, genres and criteria of relevance and has adapted to the technological options of different periods as well as to the various socio-cultural configurations. In the different periods, the precepts of the field changed. As a social practice, new concepts of news emerged.

One observes that liquid journalism is a new phase that brings many of the characteristics of informative journalism throughout the second half of the twentieth century. However, we share with Primo $(2009$, p.7) the premise that "one cannot think of the death of a certain journalism and the birth of another," because that would mean that the field would be so fragile "to the point of disintegrating, that it would not be possible to recognize it as a practice, a profession or an area of knowledge." On the other hand, it is understood that if what we are living through is not the end of journalism, possibly it signals the decline of a particular form of journalism.

Finally, it should also be noted that liquid journalism is a concept that has two faces: one derived from Barthes and Bauman who point to the critical review of the way latter-day capitalism works, and the other focused on the description of the implications of this new world order in a space of specific achievement: journalism.

Many discussions from the journalistic field, as we have seen, identify those changes in the description of the professional practices; which can lead to very serious mistakes if these descriptions do not come accompanied by a critical perspective. Examples identified here are the news centered on the reader and the personalization of the news; as if readers were outside the liquid context of society autonomously expressing their individual wills.

The liquid scenario is also the place of a great mythology - which associates democratization and enlargement of the field with a kind of plurality of merchandise, mistakenly identified as a plurality of voices. It is, indeed, the same production process - that of the liquid society of latter-day capitalism - which generates sources, journalists and readers. The porosity between such situations thus appears as the violent tableau of a historical time to be critically investigated. 


\section{NOTES}

1 Postgraduate degree thesis presented by Anelise Rublescki in the Postgraduate Program in Communication and Information at the Federal University of Rio Grande do Sul with the title "Liquid Journalism: multilevel mediation and news in flows", with the orientation of Prof. Dr. Alexandre Rocha da Silva.

2 Inside the journalistic system a plurality of subsystems is included: each print newspaper, TVs, radios, each journalistic blog, each web newspaper, as well as their correlated subsystems (sponsors, reporters, photographers, newsstands, news agencies, service providers) all can be considered subsystems, since they establish a communicational flow among themselves. Thus, journalistic practices are articulated in this article with the notion of system, subsystem and spaces for flows among their several parts. Each communication medium present on networks or off-line, the websites, the blogs, the social networks, the portals, in short, can be thought of as journalistic subsystems, under certain conditions. One follows Braga (2006, p.23) when he says that: "the expressions 'system' and 'subsystems' are interchangeable" - one system can always be part of another one, more comprehensive (therefore, a subsystem of the latter). In this article, the journalistic system is the subject of study.

3 For Bourdieu (2010, p. 44), "the contingencies associated with a particular class of conditions of existence produce the habitus, systems of durable disposition, structured structures predisposed to function as structuring structures."

\section{4 http://www.washingtonpost.com/}

5 The author used in the research were: Carrol Warren (n.d), Fraser Bond (1962), Luiz Amaral (1969), J. Galtun and M. Ruge (1965), Mar de Fontcuberta (1993), Mario Erbolato (1978), Natalício Norberto (1969), Nilson Lage (2001), P. J. Shoemaker (1991) and Teun A. van Dijk (1990).

6 Power Point presentation available at: <http://www. observatoriodaimprensa.com.br/download/342SAI001.ppt>. Accessed on: Jan. 10, 2011.

7 For Bardoel and Deuze (1999), interactivity, hypertextuality and multimediality would also be inherent characteristics of digital journalism. Machado and Palacios (2003) add also as characteristics the memory function and instantaneity, that make possible the continuous updating of the content. 


\section{REFERENCES}

ALMEIDA, Yuri. Jornalismo colaborativo: uma análise dos critérios de noticiabilidade adotados pelos cidadãos-repórteres do Brasil Wiki durante as eleições de 2008. Trabalho de conclusão da pós-graduação em Jornalismo Contemporâneo do Centro Universitário Jorge Amado, 2009.

ANDERSON, Chris. A cauda longa: do mercado de massa para o mercado de nicho. $6^{\text {a }}$ ed. Rio de Janeiro: Elsevier, 2006.

BARDOEL, Jo; DEUZE, Mark. Network Journalism: converging competences of cld and New Media Professionals, 1999. On-line. Available at: <http://users.fmg.uva.nl/mdeuze/ publ9.htm>. Accessed on: Aug.2, 2010.

BARTHES, Roland. Mitologias. Rio de Janeiro: Bertrand Brasil, 2001.

BAUMAN, Zigmunt. Vida líquida. Rio de Janeiro: Jorge Zahar, 2007

BOURDIEU, Pierre. O Poder Simbólico. 13 ed.Rio de Janeiro: Bertrand Brasil, 2010.

BRAGA, José Luiz. A sociedade enfrenta sua mídia: dispositivos sociais de crítica midiática. São Paulo: Paulus, 2006.

CASTILHO, Carlos. A riqueza de um jornal está fora das redações. Observatório da Imprensa. Online. Edição de 1/9/2009. Available at: $<$ http://carloscastilho.posterous.com/a-grande-riqueza-de-um-jornalesta-fora-das-r >. Accessed on Feb. 27, 2011.

Pensata sobre as novas funções do jornalismo na era digital. Observatório da Imprensa. Edição de 2/1/2011. Online. Available at: < http://www.observatorio daimprensa.com.br/blogs.asp?id_blog=2 >. Accessed on: Feb. 12, 2011.

A imprensa perde espaço no noticiário local. Observatório da Imprensa. Edição de 4/3/201 la. Online. Available at: <http://www. observatorioda imprensa.com.br/blogs.asp?id_ blog=2\&id= 05AE30697C40-4F70-9B90-FFD0C82AC1BB > . Accessed on: Feb. 11, 2011.

DEUZE, Mark. Liquid journalism. International Communication Association \& American Political Science Association. Chicago: University of Illinois-Chicago, v. 16, n. 1, 2006.

FERNANDES, Mario Luiz. A proximidade como critério de noticiabilidade na notícia local. I Encontro Nacional de Pesquisadores em Jornalismo da Sociedade Brasileira de Pesquisadores em Jornalismo. Anais... SBPJor: Florianópolis, 2003

FOLETTO, Leonardo. Blogosfera e campo jornalístico: aproximações e consequências. In: AMARAL, Adriana; RECUERO, Raquel; MONTARDO, Sandra (Org). Blogs.com: estudos sobre blogs e comunicação. São Paulo: Momento Editorial, 2009. e-books. P. 199-215. Availble at: <http://www. razonypalabra.org.mx/libros/libros/blogfinal.pdf $>$. Accessed on: Feb. 28, 2011.

Os weblogs como elementos propulsores do alargamento 
do campo jornalístico. TCC (Graduação em Comunicação Social). Universidade Federal de Santa Maria, 2007.

McLUHAN, Marshall. Os meios de comunicação como extensões do homem. 20. ed. São Paulo: Cultrix, 2005.

PALACIOS, Marcos. Alargamiento del campo periodístico na era del blogging. Trabalho apresentado em colóquio na Universidade Nacional de Córdoba. Anais...Córdoba: December 2006.

Ruptura, continuidade e potencialização no jornalismo on-line: o lugar da memória. In: MACHADO, Elias; PALACIOS, Marcos. Modelos de jornalismo digital. Salvador: Calandra, 2003.

PRIMO, Alex. Prefácio. In: SOSTER, Demétrio; SILVA, Fernado Firmino. Metamorfoses jornalísticas 2: a reconfiguração da forma. Santa Cruz do Sul: Edunisc, 2009.

RODRIGUES, Adriano. Estratégias da comunicação. Lisbon: Editorial Presença, 1990.

SANT'ANNA, Francisco. Mídias das fontes: um novo ator no cenário jornalístico brasileiro. Brasília: Senado Federal, Subsecretaria de Edições Técnicas, 2009.

Anelise Rublescki is journalist, Master in Social Communication / Information Science by the covenant of the Universidade Federal do Rio de Janeiro, Brazil, - CNPq/IBICT and PhD in Communication and Information from the Universidade Federal do Rio Grande do Sul, Brazil. Post-doctorate student in the Postgraduate Program in Communication at the Universidade Federal de Santa Maria, Brazil, where she works as a professor and researcher in Journalism. Sponsored by the Coordinating Body for Perfection of University Level Personnel (Capes). E-mail: anelise_sr@hotmail.com.

Alexandre Rocha da Silva is journalist, Master and $\mathrm{PhD}$ in Communication Science from the University of Vale do Rio dos Sinos, Brazil, post-doctorate from the Université de Paris III (Sorbonne-Nouvelle), Professor of the Postgraduate Program in Communication and Information of the Faculty of Librarianship and Communication at the Universidade Federal do Rio Grande do Sul, Brazil. He has experience in the Communication area with emphasis on Semiotics, Audiovisualities and Micropolitics. Vice-coordinator of the Semiotics of Communication Research Group of the Brazilian Society of Interdisciplinary Studies of Communication (Intercom) and coordinator of the National Research Council (CNPq) Directory of Semiotics and Cultures of Communication (GPESC). E-mail: arsrocha@gmail.com.

RECEIVED ON: 03/29/2012 | APPROVED ON: 05/22/2012 